\title{
Anti-Cancer, Anti-Osteoporosis, and Molecular Docking Studies of Novel Chalcone and Epoxy Chalcone
}

\author{
Kawkab Hussein $^{1, *(\mathbb{D})}$, Nezar Shihab ${ }^{2(\mathbb{D})}$, Bahjat Saeed ${ }^{2(\mathbb{D})}$ \\ 1 Chemistry Department; College of Education for Pure Science; University of Basrah; Basrah; Iraq \\ 2 Chemistry Department; College of Education for Pure Science; University of Basrah, Basrah; Iraq; \\ nezar.latif@uobasrah.edu.iq (N.L.S.); bahjat.saeed@uobasrah.edu.iq (B.A.S.); \\ * Correspondence: kawkab.ali@uobasrah.edu.iq (K.A.H.);
}

Received: 1.05.2021; Revised: 10.10.2021; Accepted: 14.10.2021; Published: 19.11.2021

\begin{abstract}
Cancer is a leading cause of death worldwide. Osteoporosis is a bone condition that causes the bones to become porous and lose density. Discovering, searching, and develop for a drug against cancer and at the same time preventing osteoporosis is very important. Chalcone and epoxy have an interest as potential drug candidates due to their easy synthesis. The present study target compounds were screened for potential anti-cancer against different cell lines (HepG2, MDA-MB-231, A375, A549, MCF-7, and HCT116) and anti-osteoporosis against cell line (MC3T3-E1). A new series of compounds evaluation by MTT assay to determine the $\mathrm{IC}_{50}$, and study apoptosis and docking study. The most potent activities were the effects of the compounds $\mathrm{CH} 2, \mathrm{CH} 3$, and $\mathrm{CH} 4$ on the MDA-MB231 cells and those of the compounds $\mathrm{CH} 7$ and $\mathrm{CH} 9$ on the HepG2. The $\mathrm{CH} 7$ compound proved noncytotoxic but was antiproliferative and caused cell cycle arrest at the G0/G1 and G2/M phases. Also, the $\mathrm{CH} 7, \mathrm{CH} 9$, and $\mathrm{E} 1$ compounds displayed excellent anti-osteoporosis activity. The docking analysis showed good binding energy. The compounds $\mathrm{CH} 2, \mathrm{CH} 3$, and $\mathrm{CH} 4$ exhibited activity towards MDAMB-231 cells and CH7 against HepG2, with induced apoptosis and cell cycle arrest, others compounds showed no significant cytotoxic activity. While compounds $\mathrm{CH}$, $\mathrm{CH}$, $\mathrm{CH} 9$, and E1 showed good toxicity against MC3T3-E1. The molecular docking study revealed that there was evidence of good interactions and the most stable complex for inhibition.
\end{abstract}

Keywords: chalcone; epoxy chalcone; anti-cancer; anti-osteoporosis; molecular docking study.

(C) 2021 by the authors. This article is an open-access article distributed under the terms and conditions of the Creative Commons Attribution (CC BY) license (https://creativecommons.org/licenses/by/4.0/).

\section{Introduction}

The most public health danger is cancer which represents the second leading cause of mortality after heart diseases across the world, due to be one of the most intractable diseases due to rapid cell growth and proliferate uncontrollably, avoid apoptosis, invade metastasize[13]. Many studies have explored the molecular mechanism of anti-tumor effects of different compounds, which can induce dependent apoptotic cell death and regulate the expression of anti-apoptotic cells [4-6]. World Health Organization (WHO) reported new cases each year and more than 19 million people deaths in the year 2020 in world. On the other hand, lung, prostate, colorectal, stomach, and liver cancers are the most common types of cancer in men, while breast, colorectal, lung, cervical, and thyroid cancer are the most common among women[1]. Despite all years of developing drugs, cancer remains a major public health problem. Another big health problem is osteoporosis facing women and older people of both sexes. Osteoporosis is a systemic bone disease, which the bones become porous and decrease 
bone density, decreasing bone force due to bone changes. The spread of osteoporosis for any age, but most common in older adults and postmenopausal women, which is associated with a decrease in estrogen levels, make it this one of the most important challenging medical struggles for modern society with 200 million people in the world suffered from osteoporosis [7,8]. It is also linked to or worsens other diseases such as diabetic osteoporosis (DOP) [9], is characterized by difficult bone healing; furthermore, the most dangerous factor for bone loss and fractures is cancer due to third most common site of cancer in the bone [10-13]. Consequently, a large number of disease cases and their lack of treatment have resulted in an urgent need to discover and develop new drug targets. The path to drug discovery is long, challenging, and arduous. The drug discovery process is crucial and carries out many assays with high cost and time. These are the major hurdles that the pharmaceutical industry faces nowadays. To overcome these challenges, molecular docking is an exemplary tool, representing the first stage to find hits from existing chemicals for drug discovery. It is molecular docking can help us significantly accelerate the process and improve chances for finding the desired drug candidates through understanding the interaction between protein and small molecule, which reduces the high cost and time for drug discovery [14-17]. One major global health challenge with numerous therapeutic strategies has been designed to discover and develop new drugs. Chalcones are described to possess many biological properties, consequently of an enone pharmacophore in their structures as well as low molecular weight compounds, easy to prepare cost-effectively, thus have encouraged to be developed as drug candidates for different diseases. Chalcones exhibit a broad spectrum of biological properties including, anti-inflammatory, anti-cancer, antibacterial, antifungal, and antiviral [18-23]. In contrast, epoxy chalcone is considered one of the most important compounds due to its biological and pharmaceutical activities [24,25] and as intermediates and precursors for a wide range of chiral compounds and the key steps of natural products [26,27]. In this work, new compounds were examined as potential anti-cancer and anti-osteoporosis products and molecular docking studies. According to a review that was conducted, such a study has not been carried out to date.

\section{Materials and Methods}

The experimental data of compounds under study has been taken from reference

[28] ( Table 1) to continue our earlier research work.

\subsection{Biological activity studies.}

The tests (anti-cancer and anti-osteoporosis) used in the study performed by MTT assay $[29,30]$ to determine cell viability with different concentrations $(3.5,7.5,15.5,30.5,60.5,121.5$, and $250 \mu \mathrm{M}$ ) along with $\mathrm{IC}_{50}$ (half maximal inhibitory concentration) calculated by GraphPad Prism software (Version 8.0.2).

\subsection{In vitro anti-cancer and activity study.}

The study of the anti-cancer activity of the compounds was carried out at Tehran University. 


\subsection{In vitro anti-osteoporosis activity.}

The study into the anti-osteoporosis activity of the compounds was carried out at Tehran University.

\subsection{Flow cytometry and cell cycle arrest.}

To detect early-stage apoptosis and the percentage of apoptotic cells in (HepG2) in the $\mathrm{CH} 7$ compound, apoptosis was determined through an Annexin V-FITC assay and, depending on the protocols, and standard flow cytometry was performed at Tehran University.

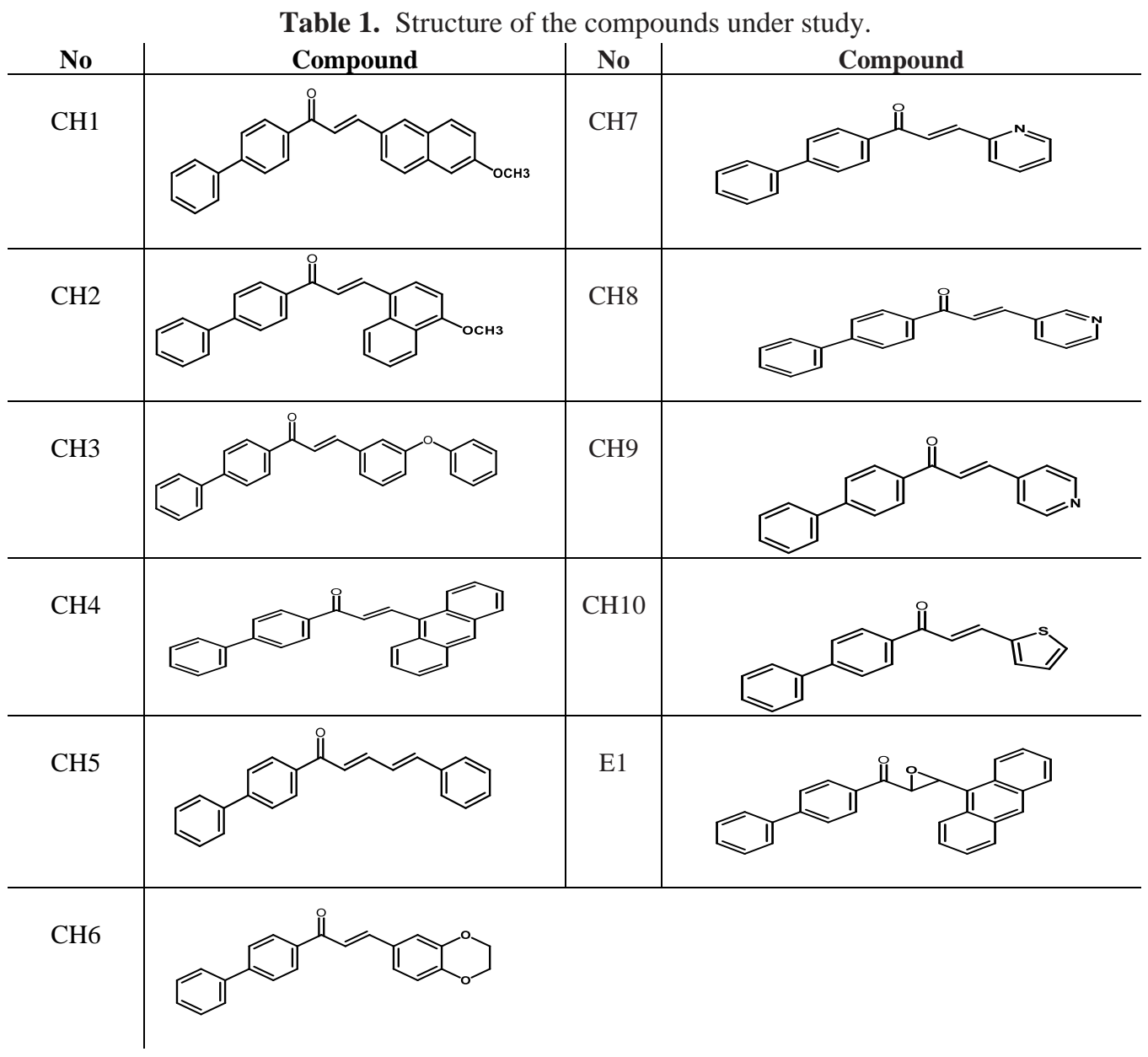

\section{Results and Discussion}

\subsection{Biological activity in vitro anti-cancer assay.}

Four compounds, $\mathrm{CH} 7, \mathrm{CH} 8, \mathrm{CH} 9$, and $\mathrm{E} 1$, which comprised three chalcones and one epoxy chalcone, were evaluated against different kinds of cancer cell lines (A375 melanoma cancer, A549 lung cancer, MCF-7 breast cancer), while the compounds, $\mathrm{CH} 1-\mathrm{CH} 10$ and E1, were examined against the colon cancer cell line, HCT116. Unfortunately, the results for all these compounds exhibited low toxicity (no significant cytotoxic activity) against all these cell lines [31,32]. The cell viability percentages versus different concentrations of the compounds are shown in Figure 1.

Meanwhile, the chalcone compounds (CH1-CH10) were tested against the MDA-MB231 cell line. The results showed that the compounds had low toxicity, except for the $\mathrm{CH} 2$, $\mathrm{CH} 3$, and $\mathrm{CH} 4$ compounds, which showed moderate toxicity and a clear reduction in the 
viability of the breast cancer cells in Figure 2. The concentration of $250 \mu \mathrm{M}$ had a moderate cytotoxic effect on these cells. The results showed that the highest concentration of the compounds significantly lowered cell viability. The $\mathrm{IC}_{50}$ values for the $\mathrm{CH} 2, \mathrm{CH} 3$, and $\mathrm{CH} 4$ compounds versus the MDA-MB-231 cell line showed good activity for all the title compounds. The inhibitory activity is shown in Figure $2(\mathrm{~B}, \mathrm{C}$, and $\mathrm{D})$, and the $\mathrm{IC}_{50}$ values are presented in Table 2.
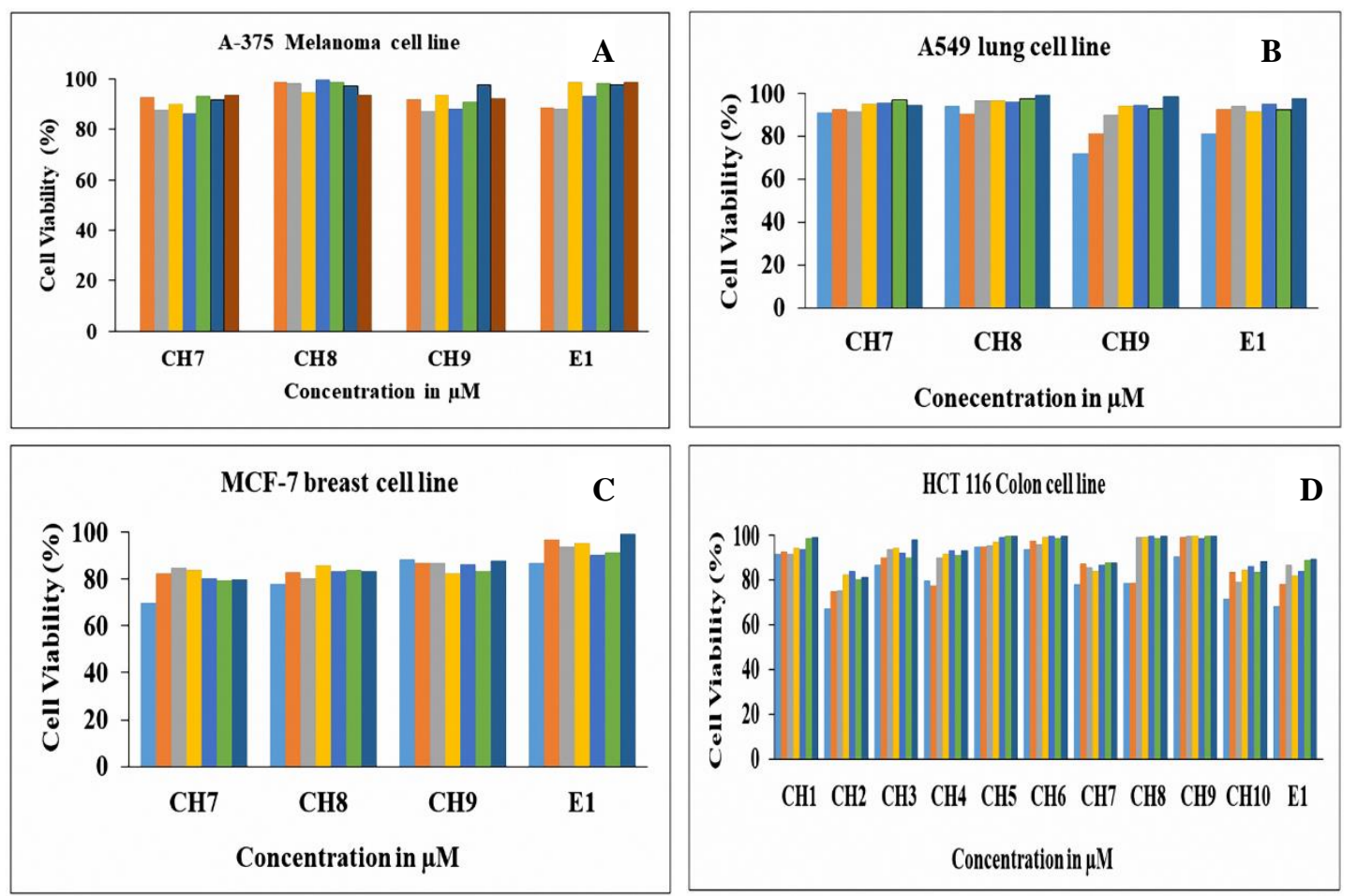

Figure 1. Percentage of the viability of cell lines ((A) A-375; (B) A549; (C) MCF-7; (D) HCT116, treated with seven concentrations of compounds.
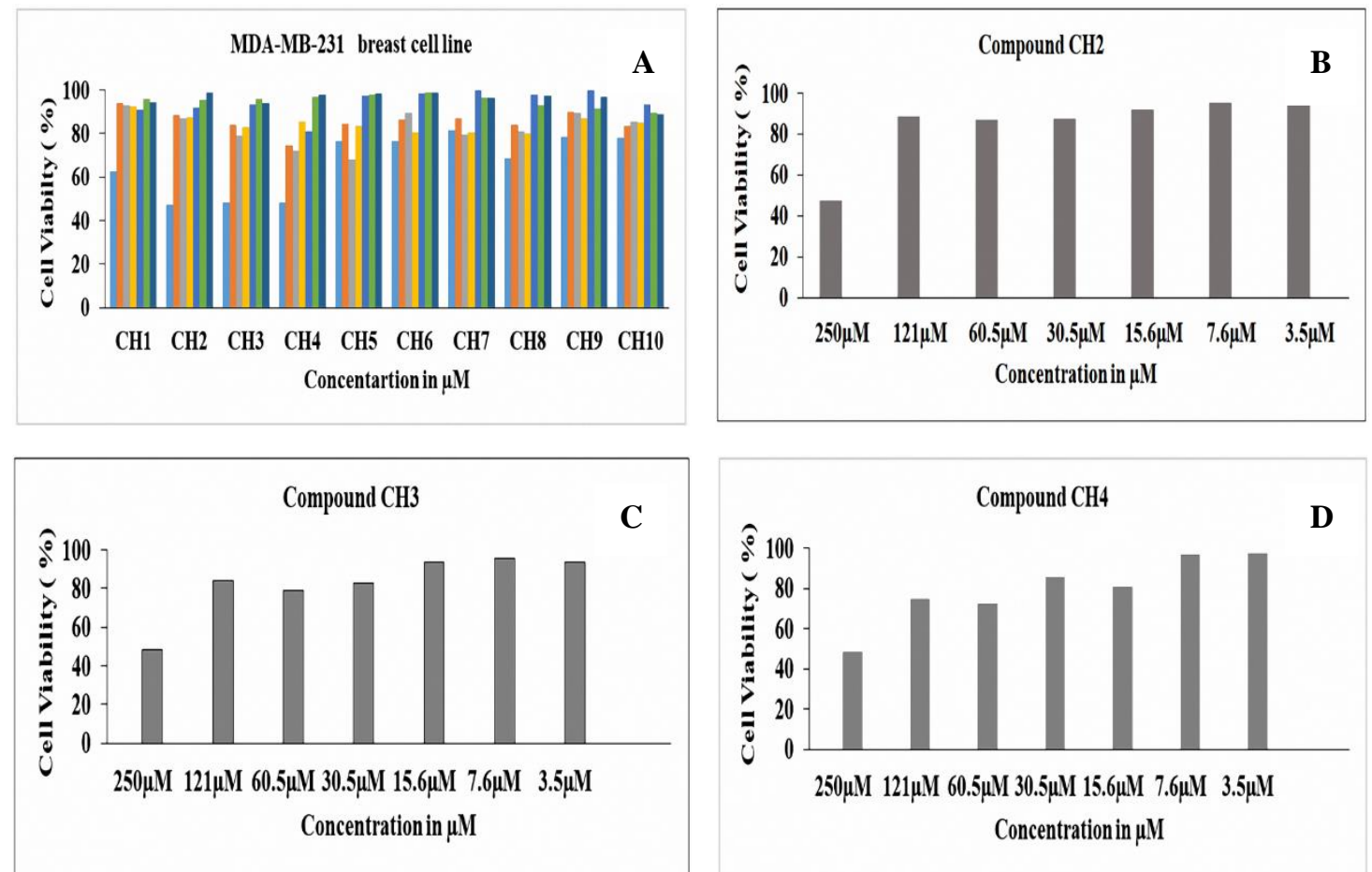

Figure 2. (A) Percentage of the viability of breast cell line (MDA-MB-231), treated with seven concentrations of compounds; $\mathrm{B}, \mathrm{C}, \mathrm{D}$. Matt assay to estimate $\mathrm{IC}_{50}$, treated with seven concentrations of compound $(\mathbf{B}) \mathrm{CH} 2$;

(C) $\mathrm{CH} 3$; (D)CH4. 
Table 2. Cytotoxic activity of the tested compounds against the MDA-MB-231 cell line.

\begin{tabular}{c|c|c}
\multicolumn{3}{|c}{ MTT assay MDA-MB-231 cell line } \\
\hline Compound & IC $_{\mathbf{5 0}}(\boldsymbol{\mu M})$ & Log IC $\mathbf{I}_{\mathbf{5 0}}(\boldsymbol{\mu M})$ \\
\hline $\mathrm{CH} 2$ & 225.9 & 2.354 \\
\hline $\mathrm{CH} 3$ & 278.9 & 2.445 \\
\hline $\mathrm{CH} 4$ & 279.1 & 2.446
\end{tabular}

In contrast, the chalcone compounds $(\mathrm{CH} 1-\mathrm{CH} 10)$ were tested against the HepG2 cell line. The results showed that the compounds $\mathrm{CH} 1-\mathrm{CH} 6, \mathrm{CH} 8$, and $\mathrm{CH} 10$, exhibited low toxicity, while the compounds, $\mathrm{CH} 7$ and $\mathrm{CH} 9$, displayed moderate toxicity, thereby significantly reducing the cell viability shown in Figure 3. According to the MTT experimental results for the $\mathrm{HepG} 2$ cell line, the $\mathrm{CH} 7$ and $\mathrm{CH} 9$ compounds exhibited considerable activity, where the average $\mathrm{IC}_{50}$ was 21.6 , and the cell concentration was $78.30 \mu \mathrm{M}$, as shown in Table 3. The $\mathrm{CH} 7$ compound was selected to investigate its inhibitory mechanism by flow cytometry further and examine its cell cycle [33,34]. Apoptosis is programmed cell death (PCD). It is a mechanism by which abnormal cells commit suicide. While the cell cycle regulates cellular growth, it also causes cell proliferation during the development of cancer cells $[35,36]$. As new DNA quickly synthesizes cancer cells, the cytotoxicity of a compound can be examined by overlapping the cells with DNA replications. In the present study, a series of chalcone derivatives were synthesized and screened against the HepG2 cell line, and two compounds (CH7 and $\mathrm{CH} 9$ ) showed good activity. In a further study, the $\mathrm{CH} 7$ compound was selected for flow cytometry and a study of the cell cycle, whereby a significant action was displayed and estimated by two concentrations of half $\mathrm{IC}_{50}$ values of $60.5 \mu \mathrm{M}$ and $121.6 \mu \mathrm{M}$, as shown in Figure 4. To investigate whether the $\mathrm{CH} 7$ compound can induce apoptosis, the effect of the compound was examined using flow cytometry and cell cycle study. The late apoptosis was studied using a flow cytometric analysis and was estimated using an Annexin V-FITC assay, with two concentrations.

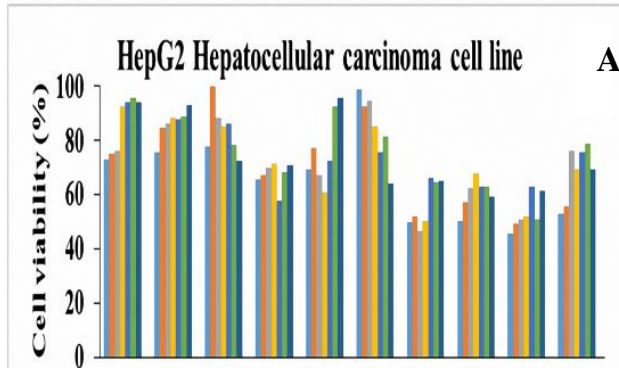

CH1 $\mathrm{CH} 2 \mathrm{CH} 3 \mathrm{CH}_{4} \mathrm{CH} 5 \mathrm{CH} 6 \mathrm{CH} 7 \mathrm{CH} 8 \mathrm{CH} 9 \mathrm{CH}_{10}$ Concentrations in $\mu \mathrm{V}$

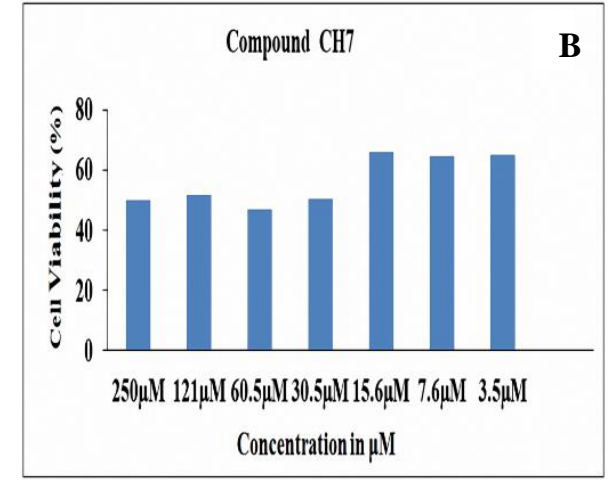

centrationin $\mu \mathrm{V}$

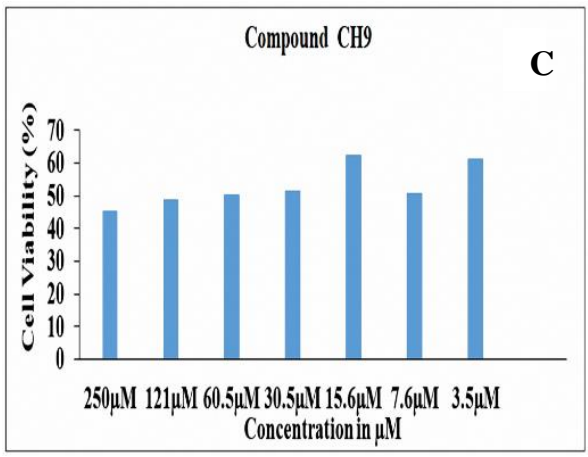

Figure 3. (A) Percentage of the viability of HepG2 cell line, treated with seven concentrations of compounds; B, C. MTT assay to estimate $\mathrm{IC}_{50}$ of $\mathrm{HepG} 2$ cell line, treated with seven concentrations of compound $\mathrm{CH}_{7}$ and CH9. 
Table 3. Cytotoxic activity of the tested compounds against the Hepg2 cell line.

MTT assay for HepG2 cell line

\begin{tabular}{c|c|c}
\hline Compound & IC $_{\mathbf{5 0}}(\boldsymbol{\mu M})$ & Log $\mathbf{I C}_{\mathbf{5 0}}(\boldsymbol{\mu M})$ \\
\hline $\mathrm{CH} 7$ & 121.6 & 2.085 \\
\hline $\mathrm{CH} 9$ & 78.30 & 1.894
\end{tabular}

The results showed a significant relationship by increasing the concentrations and comparing them with the control. The late apoptosis ratios (Q2) were $7.04 \%$ and $5.74 \%$ compared with the control ratio of $3.95 \%$, as shown in Figure 4. The cell cycle analysis in Figure 5 showed a change and decrease in the G1 and S phases, increasing the G2 phase in a concentration-dependent manner. Compared with the control value, the change in the values indicated that the $\mathrm{CH} 7$ chalcone arrested the cells at the $\mathrm{G} 2 / \mathrm{M}$ phase and induced apoptotic cell death. The tested compounds were not cytotoxic but antiproliferative, causing programmed cell death and cell cycle arrest $[37,38]$. The chemical structure of the $\mathrm{CH} 7$ compound contained nitrogen function groups, and this atom's position may have enhanced its anti-liver cancer activity.
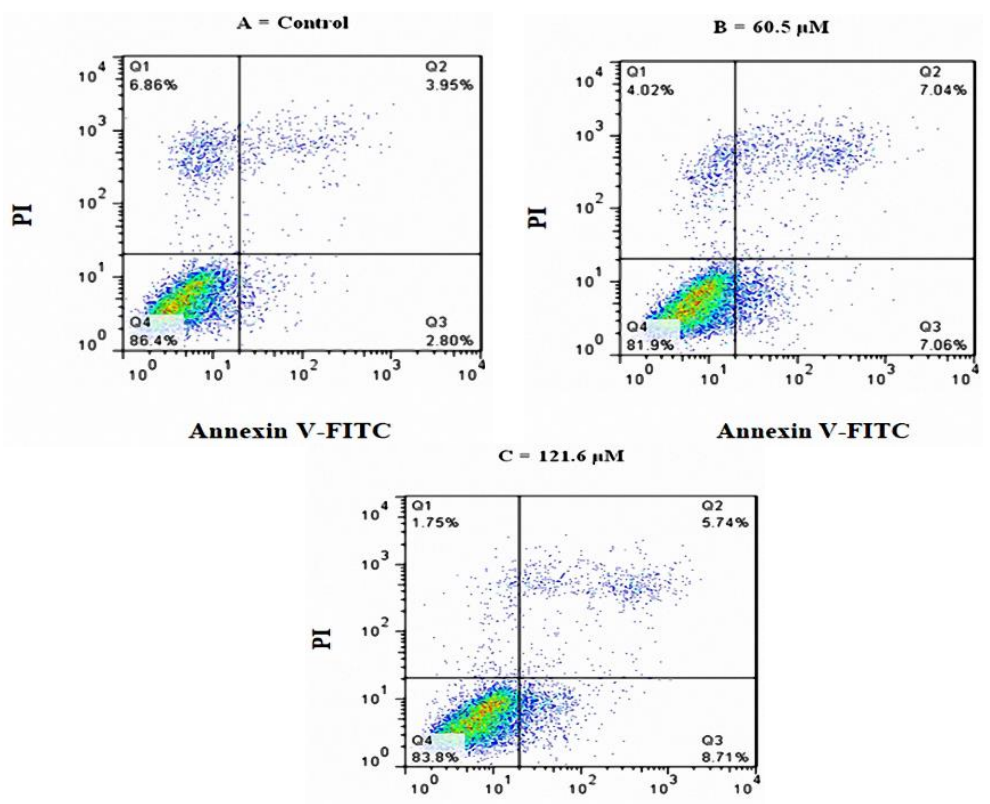

Annexin V-FITC

Figure 4. HepG2 cells were treated with compound $\mathrm{CH} 7$ (60.5 and 121.6) $\mu \mathrm{M}$ for 24 hours and processed to Annexin V assays.
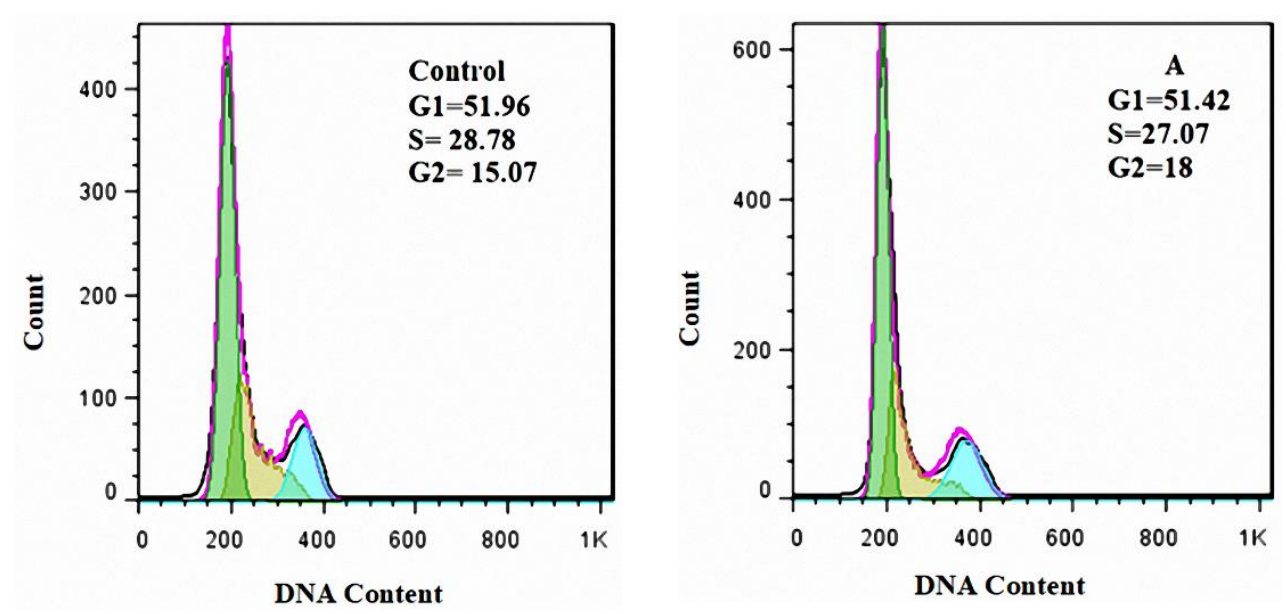

Figure 5. Effects of compound $\mathrm{CH} 7$ on $\mathrm{HepG} 2$ cell cycle progression. The cells after treatment with $\mathrm{CH} 7$ at dose $121.6 \mu \mathrm{M}$ at a period of $24 \mathrm{~h}$. 


\subsection{Anti-osteoporosis activity.}

The effects of four selected compounds ( $\mathrm{CH} 7, \mathrm{CH} 8, \mathrm{CH} 9$, and $\mathrm{E} 1)$ of chalcone and epoxy chalcone on osteoporosis were explored by testing their cytotoxicity and ability to produce osteogenesis in MC3T3-E1 cells in the calvaria of mice. It was cited over 4000 times in the literature review that these cells provide a useful model for studying bone cell proliferation [39]. The results showed that the viability of the MC3T3-E1 cells was significantly increased or decreased at certain concentrations. As shown in Figure 6, the compounds displayed good toxicity and had the highest influence on the MC3T3- E1 osteoblasts. Overall, it was obvious that the studied compounds had good activity against the cell line, except for the $\mathrm{CH} 9$ compound, which exhibited low toxicity. Table 4 shows that the $\mathrm{IC}_{50}$ values for the $\mathrm{CH} 7, \mathrm{CH} 8$, and $\mathrm{E} 1$ compounds were 127, 8.73, and 294.7, respectively, while their viability activity is shown in Figure $6(\mathrm{~B}, \mathrm{C}$, and D). From the viability results, it can be seen that the $\mathrm{CH} 7, \mathrm{CH} 8$, and $\mathrm{CH} 9$ compounds had different levels of activity because even though they have the same atoms in their structure, there are variations in the position of the nitrogen atoms. This confirmed that the position of the atoms in the structure of the compounds affected their activity. Otherwise, a comparison between the chalcone compounds, $\mathrm{CH} 7$ and $\mathrm{CH} 8$, and the epoxy chalcone compound, E1, showed that all the compounds had good activity, especially the $\mathrm{CH} 8$ compound, but it is worth mentioning that the epoxy chalcone compound, E1, did not improve or change the anti-osteoporotic activity more than the chalcone compounds, despite the presence of the oxygen atom in its heterocyclic structure. This confirmed the good activity of chalcone compounds compared to heterocyclic compounds, which means that less time, steps, and costs are involved in synthesizing chalcone than epoxy chalcone. Briefly, the compounds proved to have anti-osteoporosis properties against the proliferation of MC3T3E1 osteoblasts [40].
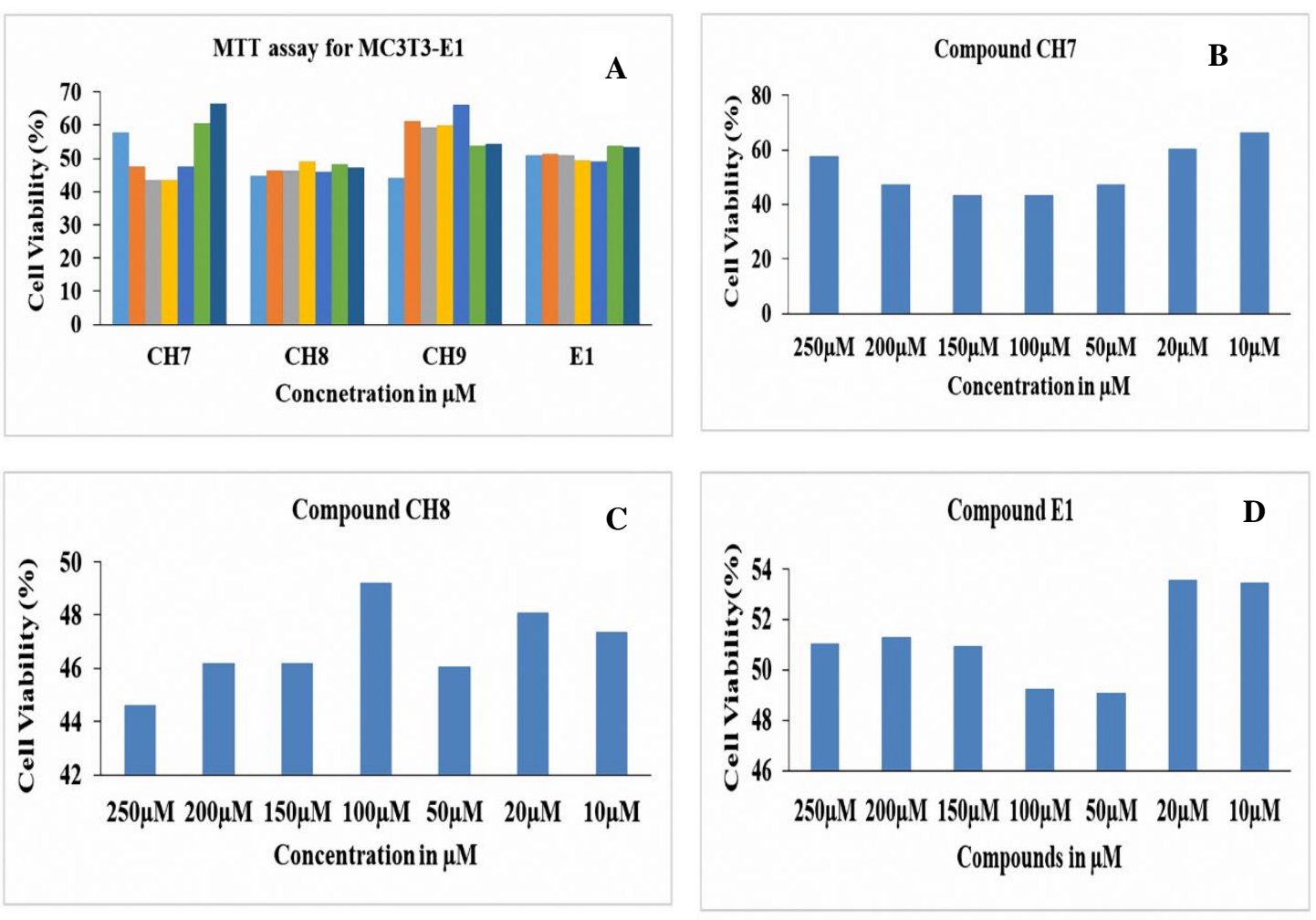

Figure 6. (A) Cell viability of the MC3T3-E1 cells, the cells were treated with seven concentrations of compounds; $\mathrm{B}, \mathrm{C}$, and D. Matt assay to estimate $\mathrm{IC}_{50}$ of MC3T3-E1 cell line, treated with se concentration of compound (B) $\mathrm{CH} 7$; (C) CH8; (D) E1. 
Table 4. Cytotoxic activity of the tested compounds against the MC3T3-E1 cell line.

\begin{tabular}{c|c|c}
\multicolumn{3}{c}{ MTT assay MC3T3-E1 cell line } \\
\hline Compound & IC $_{\mathbf{5 0}}(\boldsymbol{\mu M})$ & Log $\mathbf{I C}_{\mathbf{5 0}}(\boldsymbol{\mu M})$ \\
\hline CH7 & 127 & 2.104 \\
\hline CH8 & 8.73 & -7.059 \\
\hline E1 & 294.7 & 2.469
\end{tabular}

\subsection{Molecular docking study.}

In line with the experiments described above, molecular docking was used to estimate the binding affinity, measured in $\mathrm{kcal} / \mathrm{mol}$, of the compounds $\mathrm{CH} 2, \mathrm{CH} 3, \mathrm{CH} 4, \mathrm{CH} 7, \mathrm{CH} 8$, and $\mathrm{E} 1$, with the related proteins as cancer receptor targets and the binding affinity of the compounds $\mathrm{CH} 7, \mathrm{CH} 8$ and $\mathrm{E} 1$ with osteoporotic receptor targets.

\subsection{Selection of several proteins as cancer receptor targets.}

The experimental data showed that CDK1/CDK2 regulated the G2/M-phase to block the division of cells. According to the experimental results, the cell cycle was arrested, which indicated that the $\mathrm{CH} 7$ compound inhibited the proliferation of the HepG2 cells while inducing apoptosis and blocking the progression of the cell cycle in the $\mathrm{G} 2 / \mathrm{M}$ phase derived from the cyclin-dependent kinases (CDKs). These represented one of the key cellular kinases involved in regulating the cell cycle in the liver. Consequently, the cyclin-dependent kinase1 (CDK1) and cyclin-dependent kinase2 (CDK2) were selected as the receptor targets [41,42]. To further investigate and study these compounds for further testing through the potential molecular targets, various receptors [43-46] were used, such as plasma membrane, cytoplasm, microtubules, and nuclei, which play a significant role as anti-apoptotic proteins and are responsible for a variety of fundamental cellular processes, DNA damage and cell division $[47,48]$.

\subsection{Selected receptors and preparation of the ligand.}

The X-ray crystal structures of all the PDB proteins [49] for breast cancer, the selected proteins were:ER $\alpha$ (ID: 2IOG): ER $\beta$ (ID: 3OLS), mTOR (ID: 4FA6), VEGFR-2 (ID: 1YWN), EGFR (ID: 1M17), while for hepatocellular cancer were: CDK1 (ID: 4Y72), CDK2 (ID: 4FX3), TOPII $\alpha$ (ID: 1ZXM), Tubulin (ID: 1SA0), Bc12 (ID: 2O21), P53 (ID: 4ZYF), EGFR (ID: 1M17), VEGFR-2 (ID: 1YWN), PDGFR (ID: 5K5X), AKT (ID: 4EJN), DNA (ID: 3HB5). And the osteoporotic receptors were: IGF-1/PI3K/mTOR (ID: 5HZN), $\alpha v \beta 3$ integrin (ID:1L5G) and FPPS (ID: 2F7M). All the water molecules were removed from each protein, and hydrogen atoms were added to the receptor proteins. For the ligand, Chem. Draw Ultra 10.0 was used for the drawn molecules by the mol 2 format. Then, these were exported into the project of the Gaussian software for energy minimization by the B3LYP/6-311+G (2d, p) level of theory. After that, the ligand was converted to the docking software for the docking.

\subsection{Docking parameters and software.}

Following the docking protocol, the docking was performed by the Auto Dock4 (AD4) package software [50] on a Linux operating system. The AutoDock 4 (AD4) software, which is more widely used and is free for academic purposes, was provided by the Molecular Graphics Laboratory, Scripps Research Institute. The grid parameters, namely, the grid centers of $60 \mathrm{X}$ $\mathrm{A} 0,60 \mathrm{YA} 0$, and $60 \mathrm{Z} \mathrm{A} 0$, and spacing of $0.375 \mathrm{~A}$, were determined using a Lamarckian genetic 
algorithm (LGA). The log file was read into an ADT (Auto Dock Tool) to analyze the docking results. The docking was performed with different receptors according to the docking protocol for the estimated mode of binding for 100 runs for all the receptors.

\subsection{Molecular docking analysis and discussion.}

The docking analysis of the receptor targets for breast cancer was performed with three compounds, $\mathrm{CH} 2, \mathrm{CH} 3$, and $\mathrm{CH} 4$, and their binding affinity towards different proteins was evaluated. The results in Table 5 show that all the compounds had good binding energy of $>-$ $8.7 \mathrm{kcal} / \mathrm{mol}$ with all the cancer-related receptors, with values closer to $-11.55 \mathrm{kcal} / \mathrm{mol}$ especially indicating effective binding. The docking study revealed that the best binding occurred between the compounds $\mathrm{CH} 2$ and $\mathrm{CH} 4$ with the estrogen receptor, alpha (ERa) (2IOG), while the compound $\mathrm{CH} 3$ had very good binding energy with the estrogen receptor, beta (ER $\beta)$, (3OLS). Table 6 shows the detailed results of the best effective binding energy. These parameters were used to estimate and evaluate the best binding and interaction to form a stable ligand-protein complex. The predicted docked confirmation between the receptor ER $\alpha$ (2IOG) and the compound $\mathrm{CH} 2$ gave binding energy of $-9.73 \mathrm{kcal} / \mathrm{mol}$, as shown by the poses in Figure 7. The $\mathrm{CH} 2$ compound formed one hydrogen bond with $\operatorname{Trp} 393$, which is essential for Era, while another interaction included a hydrophobic interaction with the LE386, ARG394, LYS449, TRP360, GLU323, RRO324, MET357, PRO325, and ARG394 amino acid residues. In contrast, the $\mathrm{CH} 3$ compound, which fitted into the active site pocket, exhibited a very good binding energy of $-11.55 \mathrm{kcal} / \mathrm{mol}$ with the estrogen receptor, beta (ER $\beta)$, (3OLS). The interaction of the $\mathrm{CH} 3$ compound with the protein residues showed two hydrogen bonds, the first being between ARG346 and the oxygen carbonyl atom in chalcone, while the second was between LYS4O1 and the oxygen atom in phenoxy phenyl-chalcone. There were more interactions via hydrophobic interactions with the HIS279, TYR397, GLY342, PRO277, LEU339, GLU3O5, LEU298, ALA302, THR299, and LEU476 molecules, as shown in Figure 8. Meanwhile, the binding of the $\mathrm{CH} 4$ compound to the estrogen receptor, alpha (ERa), was stabilized at $-10.83 \mathrm{kcal} / \mathrm{mol}$. The $\mathrm{CH} 4$ compound, containing five aromatic rings surrounded by different amino acid residues, resulted in a hydrophobic interaction with the TRP393, PHE445, GLY390, ARG394, GLU323, PRO324, MET357, GLU353, and ILE326 residues. These amino acids pushed the compound deeper into the active site. As a consequence, there was better binding energy, while the lysine, LYS449, had a complex cation- $\pi$ interaction with the aromatic group. Although there was no formation of any hydrogen bonds, the interaction produced high binding energy of $-10.83 \mathrm{kcal} / \mathrm{mol}$, indicating its high affinity with the (ERa), as shown in Figure 9. When a comparison was made between the compounds $\mathrm{CH} 2$ and $\mathrm{CH} 4$, with the same protein, the $\mathrm{CH} 4$ compound gave greater docking scores than $\mathrm{CH} 2$. This may be attributed to the existence of three aromatic rings (anthracene), which generated more hydrophobic interactions. In general, the results revealed that three compounds $(\mathrm{CH} 2, \mathrm{CH} 3$, and $\mathrm{CH} 4)$ that were tested with six proteins showed good docking scores, especially with $\operatorname{ER} \alpha$ and $\operatorname{Er} \beta$, which gave the highest docked binding. This induced high stability in the ligand-protein complex, which led to the inhibition of the ER $\alpha$ and ER $\beta$ signaling pathways in breast cancer [51]. The results proved the probable role of these compounds in apoptotic cell death in breast cancer. 
Table 5. Mean docked energy for all the proteins.

\begin{tabular}{|c|c|c|c|c|}
\hline $\begin{array}{l}\text { No of } \\
\text { Proteins }\end{array}$ & Proteins & ID & Compounds & $\begin{array}{c}\text { Binding } \\
\text { Energy } \\
\text { Kcal/mol }\end{array}$ \\
\hline \multirow[t]{3}{*}{1} & \multirow[t]{3}{*}{ Er $\alpha$} & \multirow[t]{3}{*}{$2 \mathrm{IOG}$} & $\mathrm{CH} 2$ & -9.73 \\
\hline & & & $\mathrm{CH} 3$ & -10.06 \\
\hline & & & $\mathrm{CH} 4$ & -10.83 \\
\hline \multirow[t]{3}{*}{2} & \multirow[t]{3}{*}{$\operatorname{Er} \beta$} & \multirow[t]{3}{*}{$3 \mathrm{OLS}$} & $\mathrm{CH} 2$ & -9.57 \\
\hline & & & $\mathrm{CH} 3$ & -11.55 \\
\hline & & & $\mathrm{CH} 4$ & -9.12 \\
\hline \multirow[t]{3}{*}{3} & \multirow[t]{3}{*}{ mTOR } & \multirow[t]{3}{*}{ 4FA6 } & $\mathrm{CH} 2$ & -9.13 \\
\hline & & & $\mathrm{CH} 3$ & -8.9 \\
\hline & & & $\mathrm{CH} 4$ & -9.25 \\
\hline \multirow[t]{3}{*}{4} & \multirow[t]{3}{*}{ VEGFR-2 } & \multirow[t]{3}{*}{$1 \mathrm{YWN}$} & $\mathrm{CH} 2$ & -8.99 \\
\hline & & & $\mathrm{CH} 3$ & -9.17 \\
\hline & & & $\mathrm{CH} 4$ & -9.99 \\
\hline \multirow[t]{3}{*}{5} & \multirow[t]{3}{*}{ EGFR } & \multirow[t]{3}{*}{$1 \mathrm{M} 17$} & $\mathrm{CH} 2$ & -8.73 \\
\hline & & & $\mathrm{CH} 3$ & -9.34 \\
\hline & & & $\mathrm{CH} 4$ & -10.04 \\
\hline
\end{tabular}

Table 6. Selected parameters of the compound $\mathrm{CH} 2, \mathrm{CH} 3, \mathrm{CH} 4$ with the best conformer with different proteins in temperature $(\mathrm{K})$ at $298 \mathrm{k}$. Docking Properties by Autodock 4.

\begin{tabular}{c|c|c|c|c|c|c|c|c|c|c|c} 
Co & pdb & B.E & Ki um & I.E & V+B+D & E.E & F.T.I & T.E & $\begin{array}{c}\text { Unbound } \\
\text { S.E }\end{array}$ & $\begin{array}{c}\text { No. of } \\
\text { H-B }\end{array}$ & $\begin{array}{c}\text { Length } \\
\text { of } \\
\text { H-B } \mathbf{A}^{\mathbf{0}}\end{array}$ \\
\hline CH2 & 2IOG & -9.73 & 73.92 & -11.03 & -8.27 & -0.24 & -0.54 & 1.49 & -0.86 & $1 \mathrm{H}$ & 3.090 \\
\hline CH3 & 3OLS & -11.55 & 3.44 & -13.29 & -9.13 & -0.09 & -1.10 & 1.70 & -1.09 & $2 \mathrm{H}$ & 2.097 \\
\hline CH4 & 2IOG & -10.83 & 11.51 & -12.01 & -8.62 & -0.07 & -0.97 & 1.19 & -0.95 & ------ & ----
\end{tabular}

Definition of descriptors used in Table 6: $\mathrm{PDB}=$ protein data bank, B. E= Binding energy, $\mathrm{Ki}=\mathrm{Inhibition}$ Constant, $\mathrm{I} . \mathrm{E}=$ Intermolecular energy, $\mathrm{V}+\mathrm{B}+\mathrm{D}=\mathrm{VdW}+\mathrm{Hbond}+$ desolv Energy, $\mathrm{E} . \mathrm{E}=$ Electrostatic energy, F.T. I= Final total internal, T. E= Torsional energy and Unbound S. E= Unbound System's energy.

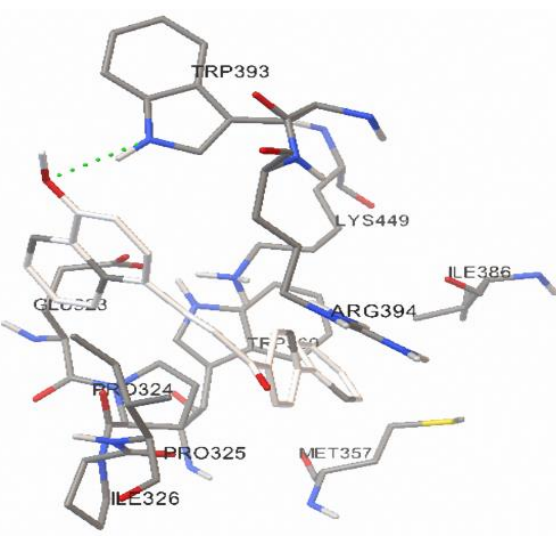

A.Stick representation

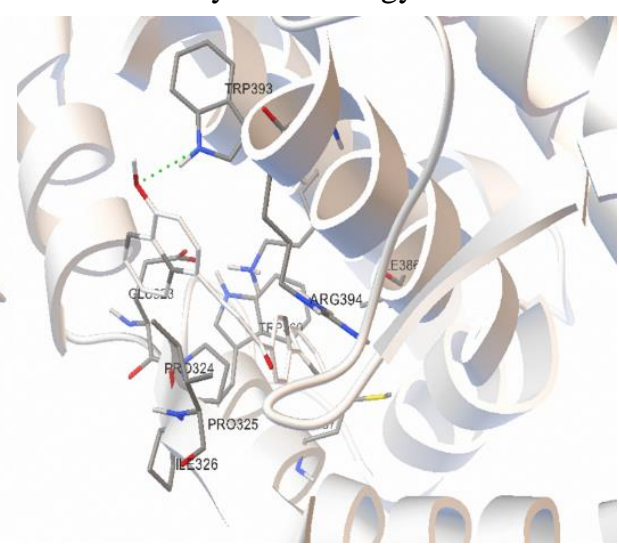

B. Ribbon format

Figure 7. Best pose and orientation for interaction compound $\mathrm{CH} 2$ with protein residues.
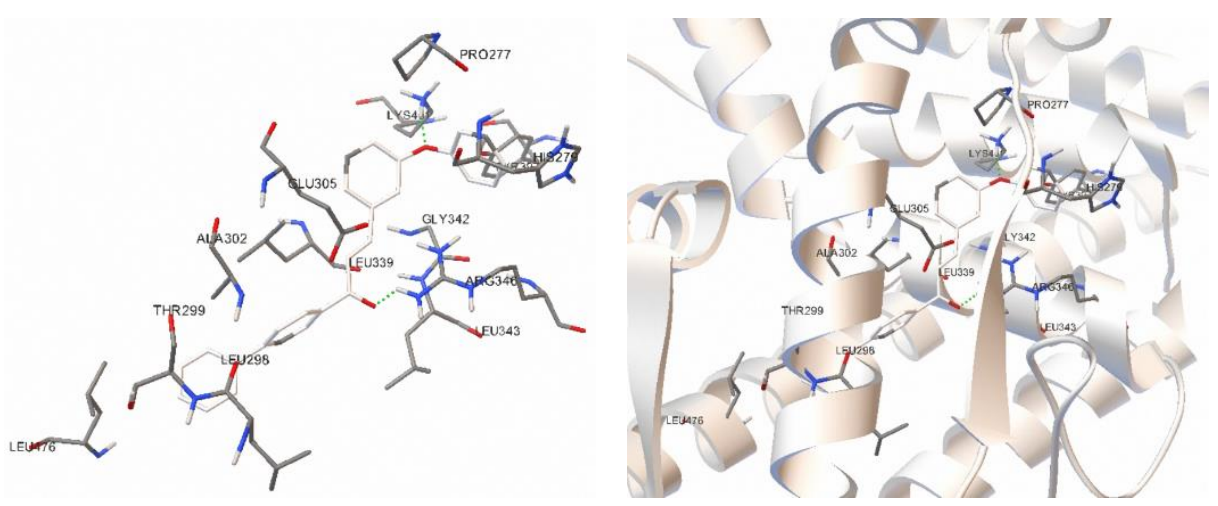

A. Stick representation; B. Ribbon format

Figure 8. Best pose and orientation for interaction compound $\mathrm{CH} 3$ with protein residues. 


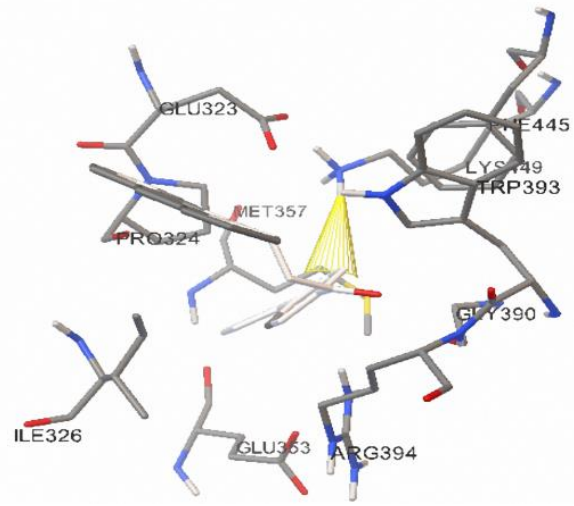

A. Stick representation

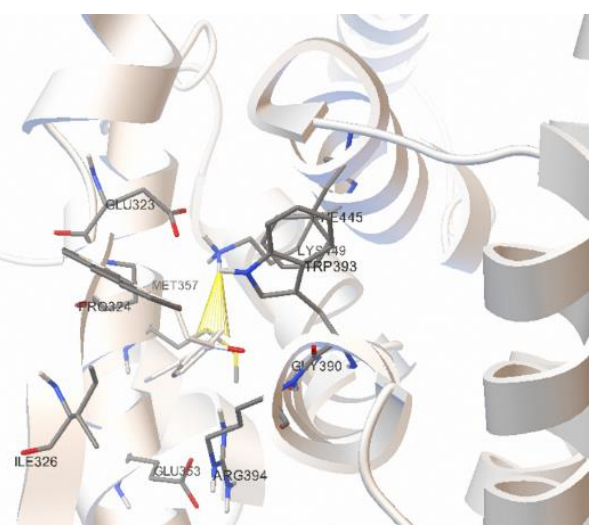

B. Ribbon format

Figure 9. Best pose and orientation for interaction compound $\mathrm{CH} 4$ with protein residues.

Meanwhile, a docking analysis was performed for the receptor targets for liver cells with the $\mathrm{CH} 7$ compound, and the binding affinity was evaluated. Table 7 reveals that all the docking results exhibited moderate to high binding of -7.22 to $-9.42 \mathrm{kcal} / \mathrm{mol}$. On the other hand, there were moderate and similar binding energies for the compound $\mathrm{CH} 7$ in the range of -7.22 to $-7.95 \mathrm{kcal} / \mathrm{mol}$ with the proteins 4Y72, 4FX3, 1ZXM, 2O21, 4ZYF, 1M17, 1YWN, and 5K5X. In contrast, among all the proteins, the tubulin, DNA, and AKT proteins showed good binding affinities of $-8.53,-8.77$, and $-9.42 \mathrm{kcal} / \mathrm{mol}$, respectively, with the $\mathrm{CH} 7 \mathrm{compound}$. According to the binding energy for tubulin protein, the $\mathrm{CH} 7$ compound acted as a destabilizing agent that blocked the tubulin from polymerizing. Another good binding affinity was with the DNA protein. According to many reports, DNA is an important goal for numerous drugs, but at the same time, the DNA can undergo cellular damage (DNA damage), whereby it is unable to fix itself. Therefore, the inhibition of DNA is a crucial goal in cancer therapy. The docking results revealed that the $\mathrm{CH} 7$ compound has the potential to be a good inhibitor of DNA. After checking the results, the best scores were investigated and presented in detail (pose and orientation). It was clearly shown that the $\mathrm{CH} 7$ compound had the highest docking score of $9.42 \mathrm{kcal} / \mathrm{mol}$ with the protein AKT/4EJN, displayed very good overlapping in the pocketreceptor, established many common interactions such as $\pi-\pi$ interactions and hydrogen bonds, and it was noticeable that all the aromatic rings in the $\mathrm{CH} 7$ compound were surrounded by the hydrophobic residues ASP292, THR291, THR211, TYR272, LEU210, VAL270, and LYS268. Also, two hydrogen bonds were exhibited, the first between SER205-NH and the oxygen atom in chalcone and the second between pyridine-N and the backbone-NH of THR21. In addition, pi-pi interactions occurred between the TRP80 amino acid and biphenyl ketone. The two hydrogen bonds, pi-pi interactions, and the groups of hydrophobic protein atoms enclosing the hydrophobic molecule atoms kept the $\mathrm{CH} 7$ compound tightly bound to the proteins and produced a highly stable ligand-protein complex. As a result, the $\mathrm{CH} 7$ compound exhibited a maximum docking score and affinity with the protein AKT/ 4EJN. This virtual screening of eleven different protein targets led to identifying the AKT/4EJN protein as the best potential receptor target for the $\mathrm{CH} 7$ compound. The docking details are given in Table 8, and the best orientation and visualization of the binding site conformations are shown in Figure 10. The literature review revealed that the protein, AKT/mTOR, is responsible for the most important signaling connections with various cellular processes and apoptosis of cancer cells [52]. This, coupled with the experimental data and docking studies, indicate that $\mathrm{CH} 7$ should be recommended as a good inhibitor or suppressor of hepatocarcinogenesis (HCC) through the inhibition of AKT/ 4EJN. 
In conclusion, different families of proteins were examined with the studied compounds, and the results showed that there was good binding energy with CDK1 (4Y72), tubulin (1SAO), and DNA (3HB5), with the highest docking score being obtained from deeper interaction with AKT/4EJN. Also, it was observed that there were $\pi-\pi$ interactions of both the phenyl rings of chalcone with a crucial amino acid. This proved to be an important structural characteristic for the inhibition of hepatocellular carcinoma (HepG2).

Table 7. Mean docked energy for all the proteins with compound CH7.

\begin{tabular}{c|c|c|c} 
No & Proteins & ID & $\begin{array}{c}\text { Binding Energy } \\
\text { Kcal/mol }\end{array}$ \\
\hline 1 & CDK1 & 4 Y72 & -7.95 \\
\hline 2 & CDK2 & 4 FX3 & -7.57 \\
\hline 3 & TOP II $\alpha$ & $1 \mathrm{ZXM}$ & -7.78 \\
\hline 4 & Tubulin & 1 SAO & -8.53 \\
\hline 5 & Bcl 2 & $2 \mathrm{O} 21$ & -7.36 \\
\hline 6 & P53 & $4 \mathrm{ZYF}$ & -7.22 \\
\hline 7 & EGFR & $1 \mathrm{M} 17$ & -7.68 \\
\hline 8 & VEGFR-2 & 1 YWN & -7.28 \\
\hline 9 & PDGFR & $5 \mathrm{~K} 5 \mathrm{X}$ & -7.61 \\
\hline 10 & AKT & $4 \mathrm{EJN}$ & -9.42 \\
\hline 11 & DNA & $3 \mathrm{HB} 5$ & -8.77
\end{tabular}

Table 8. Selected parameters of the compound $\mathrm{CH} 7$ with the best conformer with proteins in temperature (K) at 298 k. Docking properties by Autodock4 kcal/mol.

\begin{tabular}{c|c|c|c|c|c|c|c|c|c|c|c} 
Co & $\begin{array}{c}\text { PDB: } \\
\text { ID }\end{array}$ & B.E & Ki um & I.E & $\begin{array}{c}\text { V+H+ } \\
\text { D }\end{array}$ & E.E & F.T.I & T.E & $\begin{array}{c}\text { Unbound } \\
\text { S.E }\end{array}$ & $\begin{array}{c}\text { No. } \\
\text { of } \\
\text { H-B }\end{array}$ & $\begin{array}{c}\text { Length of } \\
\mathbf{H}^{\mathbf{B}} \mathbf{A}^{\mathbf{0}}\end{array}$ \\
\hline $\mathrm{CH7}$ & 4EJN & -9.42 & 124.04 & 10.56 & -9.05 & -0.03 & -0.70 & 1.19 & -0.67 & $2 \mathrm{H}$ & 2.133 \\
\hline
\end{tabular}

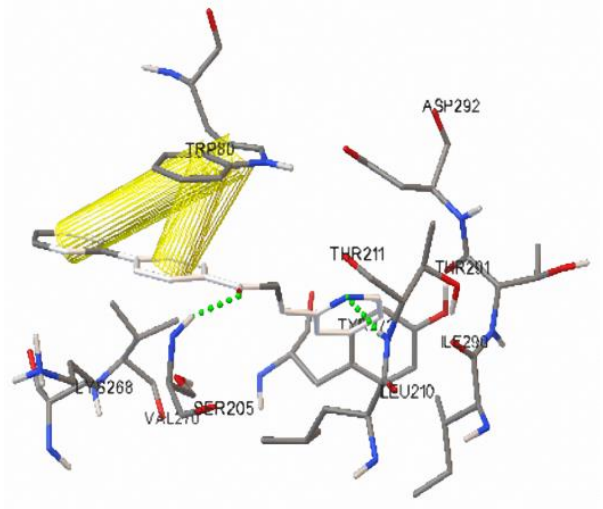

A. Stick representation

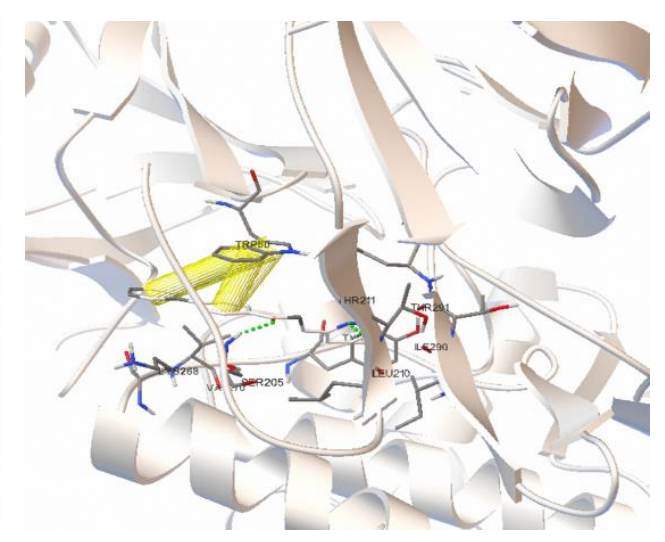

B. Ribbon format

Figure 10. Best pose and orientation for interaction compound $\mathrm{CH} 7$ with protein residues3.7. Antiosteoporotic docking analysis.

Many proteins have been correlated with bone and osteoporosis. The pathway of the IGF-1/PI3K/mTOR protein is responsible for the regulation of osteoblastic bone creation and diabetic osteoporosis [53]. In addition, the differentiation and functions of osteoclasts are controlled by cell surface receptors such as the protein $\alpha v \beta 3$ integrin [54]. Meanwhile, human farnesyl pyrophosphate synthase (FPPS) has been used as a therapeutic target for bone resorption and bone diseases such as osteoporosis [55]. Table 9 shows similar values for the compounds $\mathrm{CH} 7$ and $\mathrm{CH} 8$ due to their similar chemical structure. Both possess the same structure, with different positions of the nitrogen atom, thereby causing a similar structural conformation within the proteins. Meanwhile, the E1 compound gave a different binding score, 
and this may be attributed to its different chemical structure. As can be observed from Table 10, good binding energy led to a good superimposition between these compounds and the receptor targets. For the $\mathrm{CH} 7$ compound, the top binding score with 5HZN was -9.89 $\mathrm{kcal} / \mathrm{mol}$. The docking analysis displayed the existence of intermolecular forces, for example, $\pi-\pi$ interactions and one hydrogen bond, with regard to $5 \mathrm{HZN}$, together with hydrophobic residues, which included PHE1044, ALA1048, PHE1007, MET1051, PHE1151, VAL1060, ASP1150, GLY1149, MET1079, GLU1077, MET1076, ALA1028, and MET1139. There was one hydrogen bond between LYS1030 and N- pyridine chalcone. This bond was surrounded by a cloud of pi-cations. In addition, there was a pi-pi interaction between one aromatic ring of chalcone and that of the PHE1151 amino acid, where the CH8 compound also exhibited good binding energy of $-9.88 \mathrm{kcal} / \mathrm{mol}$ with the protein, $5 \mathrm{HZN}$. The interaction involved hydrophobic residues, one hydrogen bond, pi-cations, and the pi-pi interaction. The hydrophobic residues included the amino acids MET1139, GLU1077, MET1076, ALA1028, LYS1030, VAL1060, MET1051, GLU1047, PHE1151, ASP1150, and GLY1149. There was one hydrogen bond between the N-pyriden chalcone and H-MET1079 residue. Another interaction included a pi-cation interaction between the one ring of biphenyl with $\mathrm{H}$ and $\mathrm{N}$ LYS1030. Meanwhile, a pi-pi interaction occurred between two aromatic cores, one ring of biphenyl ketone and the aromatic ring of the PHE1151 residue. The E1 compound, being an epoxy chalcone, differed from chalcone. Likewise, it displayed the highest binding energy of $12.51 \mathrm{kcal} / \mathrm{mol}$ with the protein $5 \mathrm{HZN}$. In contrast, there was a hydrophobic interaction with the MET1079, LEU1078, GLU1077, MET1076, ALA1028, VAL1010, VAL1060, MET1051, ALA1048, PHE1044, GLU1047, and ASP1150 residues. Another pi-cation interaction occurred between N- LYS1030 with two cores of aromatic biphenyl ketone. Also, there was a pi-pi interaction between the aromatic ring of PHE1151 residue and one core of aromatic biphenyl ketone. There was one hydrogen bond between GLY1149 and the oxygen atom of the epoxy ring. All the $\mathrm{CH} 7, \mathrm{CH} 8$, and $\mathrm{E} 1$ compounds indicated the highest binding with the 5HZN protein compared to other proteins. From all the results and the docking analysis, it could be easily observed that the best binding score of $-12.51 \mathrm{kcal} / \mathrm{mol}$ was obtained between the epoxy anthracene E1 and the protein mTOR/ $5 \mathrm{HZN}$, which is the most important protein in the regulation of osteoblastic bone creation.

Table 9. Mean docked energy for all the proteins.

\begin{tabular}{|c|c|c|c|c|}
\hline $\begin{array}{c}\text { No of } \\
\text { Proteins }\end{array}$ & Proteins & ID & Compounds & $\begin{array}{c}\text { Binding } \\
\text { Energy } \\
\text { Kcal/mol }\end{array}$ \\
\hline \multirow[t]{3}{*}{1} & \multirow[t]{3}{*}{ IGF-1/PI3K/mTOR } & \multirow[t]{3}{*}{$\overline{5 \mathrm{HZN}}$} & $\mathrm{CH} 7$ & -9.89 \\
\hline & & & $\mathrm{CH} 8$ & -9.88 \\
\hline & & & $\overline{E 1}$ & -12.51 \\
\hline \multirow[t]{3}{*}{2} & \multirow[t]{3}{*}{ FPPS } & \multirow[t]{3}{*}{$2 \mathrm{~F} 7 \mathrm{M}$} & $\mathrm{CH} 7$ & -8.56 \\
\hline & & & $\mathrm{CH} 8$ & -8.68 \\
\hline & & & E1 & -9.49 \\
\hline 3 & $\alpha \mathrm{V} \beta 3$ & $1 \mathrm{~L} 5 \mathrm{G}$ & $\mathrm{CH} 7$ & -7.51 \\
\hline
\end{tabular}

Table 10. Selected parameters of the compound CH7, CH8, E1 with the best conformer with different proteins in temperature $(\mathrm{K})$ at $298 \mathrm{k}$. Docking Properties by Autodock 4.

\begin{tabular}{c|c|c|c|c|c|c|c|c|c|c|c} 
Co & pdb & B.E & Ki nM & I.E & V+B+D & E.E & F.T.I & T.E & $\begin{array}{c}\text { Unbound } \\
\text { S.E }\end{array}$ & $\begin{array}{c}\text { No. of } \\
\text { H-B }\end{array}$ & $\begin{array}{c}\text { Length } \\
\text { of } \\
\text { H-B A }^{\mathbf{0}}\end{array}$ \\
\hline CH7 & 5HZN & -9.89 & $56.53 \mathrm{nM}$ & -10.99 & -10.95 & -0.04 & -0.76 & 1.19 & -0.67 & $1 \mathrm{H}$ & 2.195 \\
\hline CH8 & $5 \mathrm{HZN}$ & -9.88 & $57.0 \mathrm{nM}$ & -11.02 & -10.95 & -0.07 & -0.72 & 1.19 & -0.66 & $1 \mathrm{H}$ & 1.905 \\
\hline E1 & $5 \mathrm{HZN}$ & -12.51 & $674.36 \mathrm{pM}$ & -13.47 & -13.33 & -0.03 & -13.37 & 1.19 & -0.70 & $1 \mathrm{H}$ & 1.973 \\
\multicolumn{10}{l}{ https://biointerfaceresearch.com/ }
\end{tabular}


Consequently, the prevention of apoptosis can therefore be associated with the signaling pathway of 5HZN and the blocking of active osteoclasts. This can help in the development of anti-OP drugs. Figures 11, 12, and 13 present the poses and active pockets for compounds $\mathrm{CH} 7, \mathrm{CH} 8$, and E1, respectively.

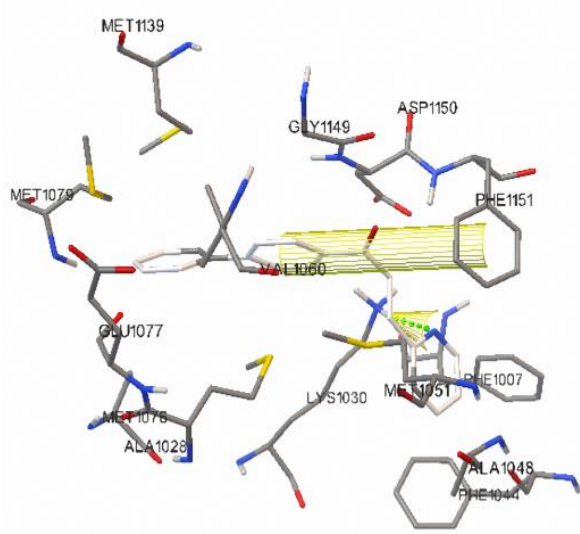

A. Stick representation

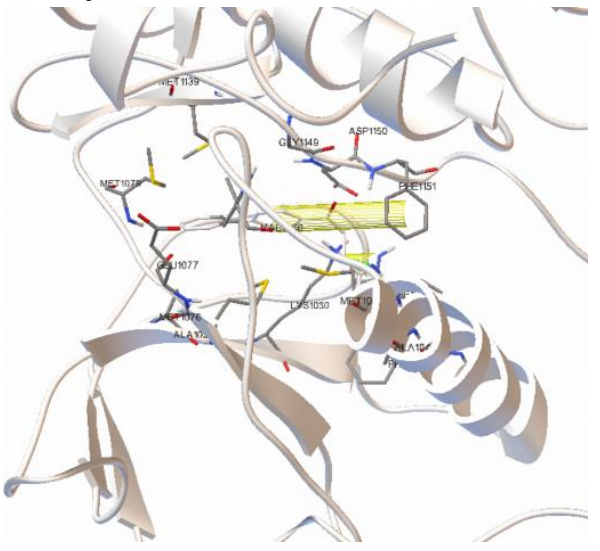

B. Ribbon format

Figure 11. Best pose and orientation for interaction compound $\mathrm{CH} 7$ with protein residues.

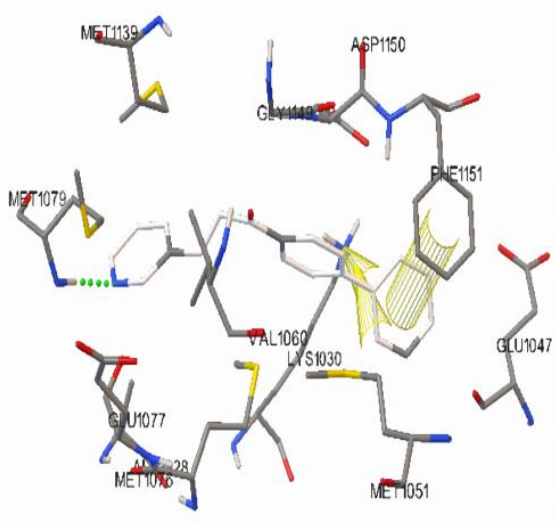

A. Stick representation

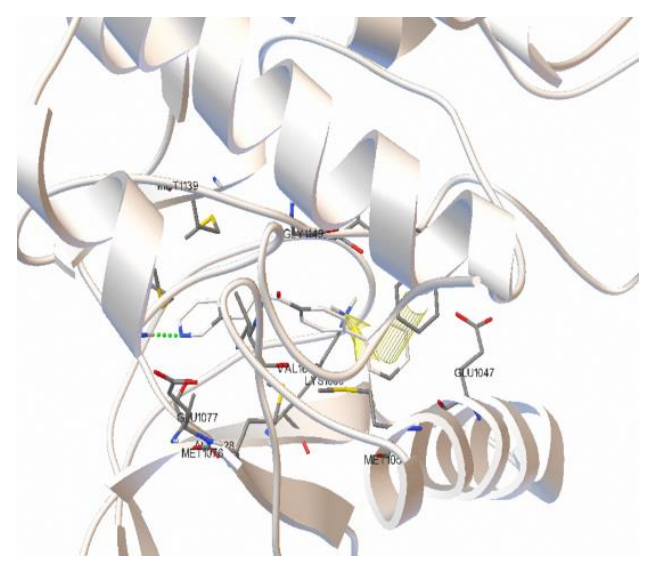

B. Ribbon format

Figure 12. Best pose and orientation for interaction compound $\mathrm{CH} 8$ with protein residues.

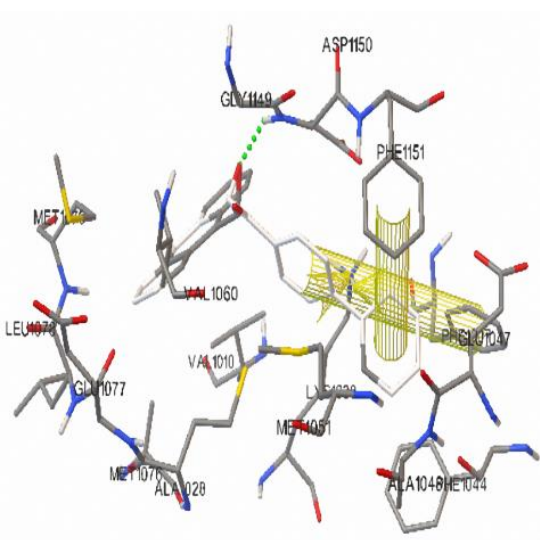

A. Stick representation

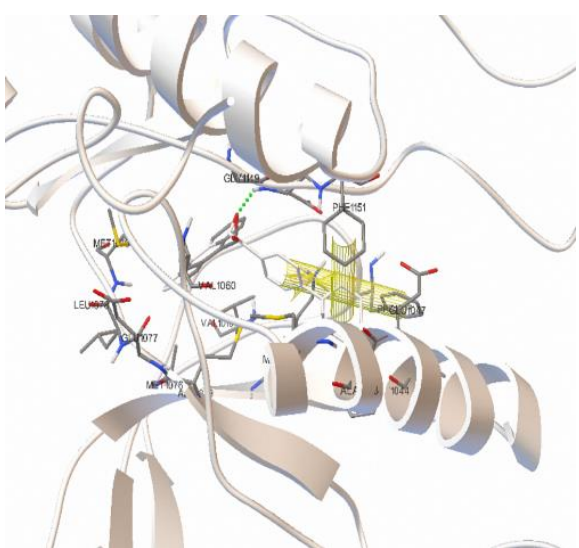

B. Ribbon format

Figure 13. Best pose and orientation for interaction compound E1 with protein residues.

\section{Conclusions}

A series of novel chalcones and epoxy chalcones were evaluated in vitro has been done. The compounds $\mathrm{CH} 2, \mathrm{CH} 3$, and $\mathrm{CH} 4$ exhibited anti-cancer activity towards MDA-MB-231 cells, while the compounds $\mathrm{CH} 7$ and $\mathrm{CH} 9$ exhibited considerable activity, and the compound 
$\mathrm{CH} 7$ induced cell cycle arrest at the G0/G1 and G2/M phases, confirming that they are not cytotoxic but antiproliferative, thereby causing programmed cell death. On the other hand, the compounds $\mathrm{CH} 7, \mathrm{CH} 8, \mathrm{CH}$, and E1 were tested against different cancer cell lines (A375 melanoma cancer, A549 lung cancer, MCF-7 breast cancer), while the compounds CH1-CH10 and E1 were tested against the HCT116 cell line for colon cancer. All the compounds showed no significant cytotoxic activity. In contrast, the compounds $\mathrm{CH} 7, \mathrm{CH} 8, \mathrm{CH} 9$, and E1 showed good toxicity and had the highest influence on MC3T3-E1 osteoblasts, except for the CH9 compound, which exhibited low toxicity. Remarkable here, compound $\mathrm{CH} 7$ showed very good activity against HepG2 and MC3T3-E1 cell lines. In silico docking studies also reveal that effective compounds $\mathrm{CH} 2, \mathrm{CH} 3$, and $\mathrm{CH} 4$, have good binding energies and binding affinities towards $\mathrm{ER} \alpha$ and $\mathrm{Er} \beta$ receptors in breast cancer. In contrast, the $\mathrm{CH} 7$ compound exhibited a maximum docking score and affinity with the protein AKT/4EJN and a good hepatocarcinogenesis (HCC) suppressor. Moreover, all the $\mathrm{CH} 7, \mathrm{CH} 8$, and $\mathrm{E} 1$ compounds indicated the highest binding with the protein responsible for regulating osteoblastic bone creation is $5 \mathrm{HZN}$. As a result, this study helps to design new therapeutic agents and suitable pharmaceutical applications.

\section{Funding}

This research project was supported by the Ministry of Higher Education and Scientific Researches, University of Basrah, College of Education for Pure Sciences, Iraq, as a part of Ph.D. graduation requirements.

\section{Acknowledgments}

The authors gratefully thank Mr. Ali to facilities for performing anti-cancer, anti-osteoporosis at the University of Tehran, Iran.

\section{Conflicts of Interest}

There are no conflicts to declare.

\section{References}

1. Hyuna, S.; Jacques, F.; Rebecca, L.S.; Mathieu, L.; Isabelle, S.; Ahmedin, J.; Freddie, B. CA Cancer J Clin 2021, 71, 209-249, https://doi.org/10.3322/caac.21660.

2. Donavon, C.H.; Gary, A.G. Implications of endoplasmic reticulum stress, the unfolded protein response and apoptosis for molecular cancer therapy. PartI: targeting p53, Mdm2, GADD153/CHOP, GRP78/BiP and heat shock proteins. Expert Opin Drug Discov 2009, 4, 799-821, https://doi.org/10.1517/17460440903052559.

3. Williams, G. H.; Stoeber, K. The cell cycle and cancer, J Pathol 2012, 226, 352-364, https://doi.org/10.1002/path.3022.

4. Debarshi, K. M.; Sanjay, K.B.; Vivek, A. Anti-cancer chalcones: Structural and molecular target perspectives. European Journal of Medicinal Chemistry 2015, 98, 69-114, https://doi.org/10.1016/j.ejmech.2015.05.004.

5. Ngoc, H.N.; Qui, T. H.T.; Quang, T. P.; Thi, N. H. L.; Van, T. P.; Thuc-Huy. D.; Van, G.V. Anticancer Activity of Novel Plant Extracts and Compounds from Adenosma bracteosum (Bonati) in Human Lung and Liver Cancer Cells. Molecules 2020, 25, 2912, https://doi.org/10.3390/molecules25122912.

6. Mohd, A. S.; Ganthala, P. D.; Sunitha, R. R.; Kumar, C. G.; Ahmed, K.; Bathini, N. B. New imidazo[2,1b]thiazole-based aryl hydrazones: unravelling their synthesis and antiproliferative and apoptosis-inducing potential. RSC Med. Chem 2020, 11, 1178-1184, https://doi.org/10.1039/d0md00188k.

7. Tümay, S.; Lale, Ö.; Nursel, C.B. An overview and management of osteoporosis, Eur J Rheumatol 2017, 41, 46-56, https://doi.org/10.5152/eurjrheum.2016.048. 
8. Lan, P. L.; Wei, J. L.; Shang, W. H.; and Jin, D. L. Health Literacy of Osteoporosis Risks among Caregivers Serving in Disability Care Facilities, Int. J. Environ. Res. Public Health 2020, 17, 4903, https://doi.org/10.3390/ijerph17134903.

9. Rufeng, M.; Ruyuan, Z.; Lili, W.; Yubo, G.; Chenyue, L.; Haixia, L.; Fengwei, L.; Hongjun, L.; Yu, L.; Main, F.; Dongwei, Z. Diabetic Osteoporosis: A Review of Its Traditional Chinese Medicinal Use and Clinical and Preclinical Research. Evidence-Based Complementary and Alternative Medicine 2016, 2016, http://dx.doi.org/10.115/2016/3218313.

10. Renata, Z.; Magdalena, K. K.; Wojciech, L.; Jerzy, W. Bone Pain in Cancer Patients: Mechanisms and Current Treatment. Int J Mol Sci 2019, 20, 6047, https://doi.org/10.3390/ijms20236047.

11. Chao, L.; Songlin, P.; Jie, L.; Jun, L.; Daogang, G.; Feng, J.; Cheng, L.; Fangfei, L.; Xiaojuan, H.; Hailong, Z.; Au, D.W.t.; Dazhi, Y.; Bao-Ting, Z.; Aiping, L.; Zhang, G. Inhibition of osteoblastic Smurf1 promotes bone formation in mouse models of distinctive age-related osteoporosis. NATURE COMMUNICATIONS 2018, 9, 3428, https://doi.org/10.1038/s41467-018-05974-z.

12. Xana, R. O.; Telmo, J. M.; David, R. T.; Rogério, C.; Fátima, C-B. Osteogenic potential of different chalcones in an in vivo model: A preliminary study. $J$ Oral Res 2017, 6, 209-215, https://doi:10.17126/joralres.2017.059.

13. Nan, W.; Jingyang, L.; Hui, S.; Chao, L.; Honggang, H.; Hongli, L.; Wei, C. Synthesis and anti-osteoporosis activity of novel Teriparatide glycosylation derivatives. $R S C A d v$ 2020, 10, 25730, https://doi.org/10.1039/d0ra05136e.

14. Richard, C. M.; Nigel, H. G. Drug discovery and development: Role of basic biological research. Alzheimer's \& Dementia: Translational Research \& Clinical Interventions 2017, 1-7, https://doi.org/10.1016/j.trci.2017.10.005.

15. Chan, H. C. S.; Hanbin, S.; Thamani, D.; Horst, V.; Shuguang, Y. Advancing Drug Discovery via Artificial Intelligence. Trends in Pharmacological Sciences 2019, 40, 8, https://doi.org/10.1016/j.tips.2019.06.004.

16. Luca, P.; Giulio, R.; Molecular Docking: Shifting Paradigms in Drug Discovery. Int. J. Mol. Sci 2019, 20, 4331, https://doi.org/10.3390/ijms20184331.

17. Jerome, D. R.; Guillaume, B.; Ralf, B.; Marc, F. L. Molecular docking as a popular tool in drug design, an in silico travel. Advances and Applications in Bioinformatics and Chemistry 2016, 9, 1-11, https://doi.org/10.2147/AABC.S105289.

18. Santosh, L. G.; Vignesh, U.N. Synthesis and pharmacological properties of chalcones: a review. Res Chem Intermed 2017, 43, 6043-6077, https://doi.org/10.1007/s11164-017-2977-5.

19. Debarshi, K. M.; Sanjay, K. B.; Vivek, A.. Anti-cancer chalcones: Structural and molecular target perspectives. European Journal of Medicinal Chemistry 2015, 98, 69-114, https://doi.org/10.1016/j.ejmech.2015.05.004.

20. Zsuzsanna, R.; Pál, P.. Naturally occurring chalcones and their biological activities, Phytochemistry Reviews 2016, 15, 87-120, https://doi.org/10.1007/s11101-014-9387-8.

21. Yan-Ling, T.; Xi, Z.; Yan, Q.; Xiao-Jia, P.; Bei, L.; Xia, Z.; Xiao-Si, L.; Wei-Lie, X.; Chun-Ping, W.; ZeWei, M. Synthesis and anti-inflammatory evaluation of new chalcone derivatives bearing bispiperazine linker as IL-1 $\beta$ inhibitors. Bioorganic Chemistry 2020, 98, 103748, https://doi.org/10.1016/j.bioorg.2020.103748.

22. Yun, F.; Dan, L.; Huanan, Z.; Xiaoli, R.; Baoan, S.; Deyu, H.; Xiuhai, G.;. New chalcone derivatives: synthesis, antiviral activity and mechanism of action. RSC Adv 2020, 10, 24483, https://doi.org/10.1039/D0RA03684F.

23. Serdar, B.; Oztekin, A.; Arzu, G.; Derya, A. A.; Mahmut, U.; Busra, G, E.; Engin, K.; Aylin, D.; Gönǔl, A. Design of potent fluoro-substituted chalcones as antimicrobial agents. Journal of Enzyme Inhibition and Medicinal Chemistry 2017, 32, 490-495, https://doi.org/10.1080/14756366.2016.1265517.

24. El-Meligie, S.; Azza, T. T.; Aliaa, M. K.; Youssef, A. Design, synthesis and cytotoxic activity of certain novel chalcone analogous compounds. European Journal of Medicinal Chemistry 2017, 126, 52-60, https://doi.org/10.1016/j.ejmech.2016.09.099.

25. Haiyong, H.; Yu, Z.; Timothy, C.; Rosemarie, F. H.; Seth, D. R. Cell Cycle Arrest and Apoptosis Induction by an Anticancer Chalcone Epoxide. Arch. Pharm. Chem. Life Sci 2010, 8, 429-439, https://doi.org/10.1002/ardp.200900261.

26. Naveen, K. K.; Naseem, A. Regioselective Opening of Chalcone Epoxides with Nitrogen Heterocycles Using Indium (III) Chloride as an Efficient Catalyst. Synthetic Communications: An International Journal for Rapid Communication of Synthetic Organic chemistry 2013,43, 2008-2018, https://doi.org 10.1080/00397911.2012.667291. 
27. Christelle, L. Epoxy ketones as versatile building blocks in organic synthesis. Tetrahedron: Asymmetry 2001, 12, 2359-2383, https://doi.org/10.1016/S0957-4166(01)00412-8.

28. Kawkab, A. H.; Nezar, L. S.; Bahjat, A. S. Synthesis, Identification and Study of the Anti-microbial activity of Novel Chalcone and Epoxy chalcone compounds. Egypt. J. Chem 2021, 64, 2297-2304, https://doi.org/10.21608/EJCHEM.2021.57012.3233.

29. Ali, A. A.A.; Mustafa, F. H.; Nashwan, H. A.; Kawakb, A. H. Investigations of Phytoconstituents, Antioxidant and Anti-Liver Cancer Activities of Saueda monoica Forssk Extracted by Microwave-Assisted Extraction. Asian Pacific Journal of Cancer Prevention 2020, 21, 2349-2355, https://doi.org/10.31557/APJCP.2020.21.8.2349.

30. Peter, T.; Martin, K.; Maria, V.; Janka, V.; Radka, M.; Gabriela, M.; Jan, M. Antiproliferative Effect of Acridine Chalcone Is Mediated by Induction of Oxidative Stress. Biomolecules 2020, 10, 345, https://doi.org/10.3390/biom10020345.

31. Ahmad, P.; S.; B.; Farzane, V.; Mahbobeh. F.; Mohammad, H.; N.; E.; Ahmad, R.; M.Synthesis and Anticancer Activity Assay of Novel Chalcone-Sulfonamide Derivatives. Iranian Journal of Pharmaceutical Research 2017,16, 565-568, https://doi.org/10.22037/IJPR.2017.2036.

32. Xuan, Z.; Wenliang, D.; YuanDi, G.; Dong-Shoo, S.; Qing, Y.; Le, S.; Fan, J.; Baoxiang, Z.; Jun, Y. M. Novel indolyl-chalcone derivatives inhibit A549 lung cancer cell growth through activating Nrf-2/HO-1 and inducing apoptosis in vitro and in vivo. Scientific Reports 2017, 7, 3919, https://doi.org/10.1038/s41598-01704411-3.

33. Hongtian, Z.; Lei, T.; Chenghong, Z.; Baochu, W.; Pingrong, Y.; Dian, H.; Lifang, Z.; Yang, Z. Synthesis of Chalcone Derivatives: Inducing Apoptosis of HepG2 Cells via Regulating Reactive Oxygen Species and Mitochondrial Pathway. Front. Pharmacol 2019, 10, 1341, https://doi.org/10.3389/fphar.2019.01341.

34. Wasitta, R.; Ratana, B. Effect of Calomelanone, a Dihydrochalcone Analogue, on Human Cancer Apoptosis/Regulated Cell Death in an In Vitro Model. BioMed Research International 2020, 2020, 1-16, https://doi.org/10.1155/2020/4926821.

35. Ouyang, L.; Shi, Z.; Zhao, S.; Wang, F. T.; Zhou, T. T.; Liu, B.; Bao, J. K. Programmed cell death pathways in cancer: a review of apoptosis, autophagy and programmed necrosis. Cell Prolif 2012, 45, 487-498, https://doi.org/10.1111/j.1365-2184.2012.00845.x.

36. Manik, D.; Kuntal, M.; Chalcone Scaffold in Anticancer Armamentarium: A Molecular Insight. J Toxicol 2016, 2016, 7651047, https://doi.org/10.1155/2016/7651047.

37. Rodrigo, R-T.; Carlos, A. E.; Valentina, R.; Ignacio, M.; Ricardo, A.; Vincenzo, B.; Emanuel, J.; Luis, P.; Felipe, S.; Cesar, E. Chalcone-Induced Apoptosis through Caspase-Dependent Intrinsic Pathways in Human Hepatocellular Carcinoma Cells. Int. J. Mol. Sci 2016, 17, 260, https://doi:10.3390/ijms17020260.

38. Guangcheng, W.; Zhiyun, P.; Yongjun, L. Synthesis, Anticancer Activity and Molecular Modeling Studies of Novel Chalcone Derivatives Containing Indole and Naphthalene Moieties as Tubulin Polymerization Inhibitors. Chem. Pharm. Bull 2019, 67, 725-728, https://doi.org/10.1248/cpb.c19-00217.

39. Phillip, W. H.; Jason, A. H. Variable osteogenic performance of MC3T3-E1 subclones impacts their utility as models of osteoblast biology. Sci Rep 2019, 9, 8299, https://doi.org/10.1038/s41598-019-44575-8.

40. Hiromi, H.; Kyoko, N.; Hitoshi, M.; Sanae, M.; Yuki, K.; Rieko, A.; Shigeki, Y.; Daichi, K.; Keitaro, H.; Kaoru, Y. 4-Hydroxyderricin inhibits osteoclast formation and accelerates osteoblast differentiation. Cytotechnology 2019, 71, 15-22, https://doi.org/10.1007/s10616-018-0236-2.

41. Dong-Jun, F.; Ping, L.; Bo-Wen, W.; Xin-xin, C.; Cheng-Bin, Z.; Sai-Yang, Z. Molecular diversity of trimethoxyphenyl-1, 2, 3-triazole hybrids as novel colchicine site tubulin polymerization inhibitors. European Journal of Medicinal Chemistry 2019, 165, 309-322, https://doi.org/10.1016/j.ejmech.2019.01.033.

42. Ghaneya, S. H.; Doaa, E. A. R.; Yassin. M. N.; Esraa, A. A.; Tamer, M. A. Novel pyrazolopyrimidines: Synthesis, in vitro cytotoxic activity and mechanistic investigation. European Journal of Medicinal Chemistry 2017, 138, 29, 565-576, https://doi.org/10.1016/j.ejmech.2017.07.003.

43. Xing, k.; Lisong, S. Molecular targeted therapy of cancer: The progress and future prospect. Frontiers in Laboratory Medicine 2017, 1, 69-75, https://doi.org/10.1016/j.flm.2017.06.001.

44. Abheepsa, M.; Satyahari, D. Molecular Docking Studies of a Cyclic Octapeptide-Cyclosaplin from Sandalwood. Biomolecules 2019, 9, 740, https://doi.org/10.3390/biom9110740.

45. Mohammad, S.J.; Shadma. P.; Mohd, A.; B.; Mohd, S.; Adeel, G.; A.; C.; Ghazi, A.; D.; Adel, M.; A.; Mohd, R. Anticancer Compound Plumbagin and Its Molecular Targets: A Structural Insight into the Inhibitory Mechanisms Using Computational Approaches. PLoS ONE 2014, 9, e87309, https://doi.org/10.1371/journal.pone.0087309. 
46. Md, Y. A.; Sumera, Z.; Mizanur, R. M.; Susoma, J.; Seong, K. P.; Mun, S. C.; Jamshed, I. Didymin, a dietary citrus flavonoid exhibits anti-diabetic complications and promotes glucose uptake through the activation of PI3K/Akt signaling pathway in insulin-resistant HepG2 cells. Chemico-Biological Interactions 2019, 305, 180-194, https://doi.org/10.1016/j.cbi.2019.03.018.

47. Claire, M. P.; Amareshwar, T. K. S. Apoptosis: A Target for Anticancer Therapy. Int. J. Mol. Sci 2018, 19, 448, https://doi.org/10.3390/ijms19020448.

48. Kaleigh, F.; Manabu, K.; Evading apoptosis in cancer. Trends Cell Biol 2013, 23, 620-633, https://doi.org/10.1016/j.tcb.2013.07.006.

49. Helen, M.; B.; John, W.; Zukang, Feng.; Gary, G.; Bhat, T.N.; Helge, W.; Ilya, N.;S.; Philip, E.; B. The protein Data Bank. Nucleic Acids Research 2000, 28, 235-242, https://doi.org/10.1093/nar/28.1.235.

50. Goodsell, D.; S.; Morris, G.; M.; Olson, A.; J. Automated Docking of Flexible Ligands: Applications of AutoDock, J. Mol. Recognition 1996, 9, 1-5, https://doi.org/10.1002/(SICI)1099-1352(199601)9:1<1::AIDJMR241>3.0.CO;2-6.

51. Rainer, G.; Günter, E.; Carsten, G. Estrogen Signaling in ER $\alpha$-Negative Breast Cancer: ER $\beta$ and GPER. Front. Endocrinol 2019, 9, 781, https://doi.org/10.3389/fendo.2018.00781.

52. Zhilin, Z.; Tao, T.; Hongmei, L.; Xiao, Z. mTOR signaling pathway and mTOR inhibitors in cancer: progress and challenges. Cell Biosci 2020, 10, 31, https://doi.org/10.1186/s13578-020-00396-1.

53. Wan, G.; Naidan, Z.; Gang, C.; Quanlong, Z.; Yuqiong, H.; Yi, S.; Qi, Z.; Bo, Z.; Qioayan, Z.; Luping, Q. Rehmannia glutinosa Libosch Extracts Prevent Bone Loss and Architectural Deterioration and Enhance Osteoblastic Bone Formation by Regulating the IGF-1/PI3K/mTOR Pathway in Streptozotocin-Induced Diabetic Rats. Int. J. Mol. Sci 2019, 20, 3964, https://doi.org/10.3390/ijms20163964.

54. Zhe, X.; Hui, C.; Zhenyu, W.; Fengjiao, F.; Pujie, S.; Maolin, T.; Ming, D. Isolation and Characterization of Peptides from Mytilus edulis with Osteogenic Activity in Mouse MC3T3-E1 Preosteoblast Cells. Journal of Agricultural and Food Chemistry 2019, 67, 1572-1584, https://doi.org/10.1021/acs.jafc.8b06530.

55. Cheong, Y.K.; Ren, G.G.; Huang, M.; Detsch, R.; Boccaccini, A. R. Biological evaluations of novel 2,3,3Trisphosphonate in osteoclastic and osteoblastic activities. Gen Med Open 2017, 2, 1-10, https://doi.org/10.15761/GMO.1000121. 